\title{
NEO-NO-FAULT REMEDIES FOR MEDICAL INJURIES: COORDINATED STATUTORY AND CONTRACTUAL ALTERNATIVES
}

\author{
JEFFrey O'CONNELL*
}

I

\section{Introduction: Faults of the Fault System and the NeEd for FunDaMENTAL REFORM}

Suits to recover for personal injuries resulting from medical malpractice can be among the most unpredictable and most complex to litigate. Because provider fault is frequently difficult to measure-even (and sometimes especially) with the assistance of the parties' alleged (and opposing) expertsa lay jury is apt to be influenced more by its subjective and emotional reaction to the injured patient's plight than by the appropriateness of the defendant's conduct. Thus, lengthy and costly litigation can yield unpredictable results, and this unpredictability raises the costs of claims evaluation and often makes settlements harder to reach. Perceptions of the system as a game of chance rather than as a sound mechanism for catching negligent behavior may undercut the system's value in raising professional standards and deterring injuries. ${ }^{1}$ If providers of health care believe that the legal system lacks the capacity to be reasonable and may penalize even the appearance of negligence, they may err in the direction of practicing inefficient "defensive medicine" by spending large amounts to make it appear that nothing was spared in the plaintiff's case.

The system's haphazardness also diminishes its value as a protection for injured patients. One seriously injured party may recover nothing at all or far less than fair compensation, while another receives an award far in excess of his actual loss. Inconsistency is enhanced by allowing juries to award damages for such noneconomic losses as pain and suffering and loss of consortium. Because monetary valuation of such nonmonetary losses is inherently irrational, plaintiffs are encouraged to play upon the jury's sympathy, further distracting attention from the issue of provider fault. The cost of the tort system is also increased, without increasing its value as a

Copyright (C) 1986 by Law and Contemporary Problems

* John Allan Love Professor of Law, University of Virginia.

The author warmly thanks George Constantinople, University of Virginia Law School, class of 1986, for his valuable help in the preparation of this article.

1. J. O'Connell, Ending Insult to Injury: No-Fault Insurance for Products and Services $44(1975)$. 
compensation device, by allowing some victims to recover from a tortfeasor amounts already reimbursed to the plaintiff by such collateral sources as health insurance or an employer's sick leave program. ${ }^{2}$

Litigation actually occurs with respect to only a small fraction of claims, and it has been argued that the claims-insurance system works better as a whole than it does in the more visible minority of cases that are contested in court. $^{3}$ Nevertheless, litigation prospects determine plaintiffs' and defendants' assessments of settlement possibilities, and substantial costs are incurred in evaluating claims. An optimal system would be one that facilitates settlement of most claims by prompt, periodic payment of the injured party's net economic loss. Yet, the unpredictable and intensely adversary nature of malpractice suits makes such settlements rare today. Defendants fear that a prompt offer to cover a victim's net economic losses might be seen as a confession of weakness and encourage the victim to pursue a larger recovery through litigation. On the other side of the case, the plaintiff's attorney, working for a contingent fee and hopeful of a "big hit," has an undue incentive to discourage settlement and take a case to trial. Because the lawyer can spread the risk of nonrecovery in a single case over an entire portfolio of claims, his interest in achieving a reasonable settlement is less than that of his client, who risks everything on a single claim.

Other factors also reduce the value of the medical malpractice system both as a deterrent to bad practice and as a compensation mechanism. First, a patient may have difficulty knowing whether a bad medical outcome resulted from negligence or some other cause, with the result that a great deal of provider negligence goes undetected and unpoliced. Second, some patients may be inhibited in bringing claims against physicians and hospital personnel whom they have depended upon and trusted. After all, a patient must, in order to recover anything at all, assume a prolonged accusatory stance toward the provider who has cared for him. Not only does this enforced adversariness reduce the number of claims that will be brought, but it adds to the difficulty of settling claims and to the psychic wear and tear of malpractice suits. The effects of the system on provider/patient relationships are among the uncalculated costs of the tort system as it has evolved in the medical care field. ${ }^{4}$

For the foregoing reasons, the tort system, especially in the area of medical malpractice-although products liability presents problems of similar

2. O'Connell, A "Neo-No-Fault" Contract in Lieu of Tort: Preaccident Guarantees of Postaccident Settlement Offers, 73 Calif. L. Rev. 898, 900-01 (1985).

3. P. Danzon \& L. Lillard, The Resolution of Medical Malpractice Claims: Research Results and Policy Implications vi-vii (The Rand Corp., Report No. R-2793-ICJ 1982).

4. A report by the Board of Trustees of the American Medical Association finds that "the biggest cost" of suits brought under the malpractice system is "the emotional injury that a physician experiences when he or she believes that he or she has done the best possible under difficult circumstances. Decreases in physician productivity as a result of such dysfunction cannot be estimated." Board of Trustees [Am. Medical Ass' n], Study of Professional Liability Costs 101 (1983) (Substitute Resolution 8, A82 Report: N(I-83)). 
magnitude ${ }^{5}$-is no longer fulfilling the purposes for which it was intended. ${ }^{6}$ The legal system's effort to devise a fair and rational method for compensating injured persons and disciplining poor professional practice has produced only a litigation lottery. Everyone paying for health care is forced to buy tickets in this lottery despite the poor chances of winning. Moreover, because winners are chosen by a complex and costly process of claims evaluation and litigation, the lottery is highly unfair, benefiting the attorneys and insurers who administer the game to a much greater degree than the involuntary players. By one estimate, the medical malpractice tort system returns to injured patients only twenty-eight cents of each dollar paid in as insurance premiums, and of that amount, only 12.5 cents reimburse the victim for economic losses not already compensated by other sources. ${ }^{7}$ Although some assert that the high cost of the system is justified by its contribution to the maintenance of high quality standards, there should certainly be no debate that there is considerable room for the public to gain from reform. ${ }^{8}$

Although tinkering with the tort system has occurred in the past and is likely to continue, fundamental reform may be more advisable. There are two possible routes to major reform. In addition to the obvious possibility of legislative change, providers and patients might voluntarily agree to assume quite different relationships than those that the law currently prescribes. Having indicated briefly why reform is desirable, this article presents and expands upon some ideas for reform that the writer has presented in other forums. ${ }^{9}$ The premises of this discussion are that better compensation for injured persons is the primary desideratum, 10 that "no-lawsuit"11 compensation is both feasible and in the consumer's interest, and that experimentation with new ideas would lead to better results than the tort system is yielding. The objective here is to show how proposals for both legislative and contractual reform using no-fault concepts, each meritorious in its own right, can be blended into a liability system that dramatically improves the present system.

5. The suggestions for legislative and contractual reform in this article could be applied to all claims for personal injury, including those from malfunctioning products. O'Connell, Offers That Can't Be Refused: Foreclosure of Personal Injury Claims by Defendants' Prompt Tender of Claimants' Net Economic Losses, 77 Nw. U.L. Rev. 589 (1982).

6. See infra notes $42-43$ and accompanying text.

7. O'Connell, An Alternative to Abandoning Tort Liability: Elective No-Fault Insurance for Many Kinds of Injuries, 60 MinN. L. REV. 501, 509 (1976).

8. Even Professor Danzon, for all her support of the present system, see supra note 3 and accompanying text, advocates very significant reforms, some of which are similar to those advanced in the legislative and contractual proposals made herein. P. DANzoN \& L. Lillard, supra note 3, at 30-32.

9. Moore \& O'Connell, Foreclosing Medical Malpractice Claims by Prompt Tender of Economic Loss, 44 LA. L. REv. 1267, 1278-87 (1984); O'Connell, supra notes 2 and 5.

10. O'Connell, supra note 5 , at 620 .

11. The statutory device proposed herein is not, strictly speaking, one for no-fault insurance. See infra note 37 and accompanying text. It is designed to avoid lawsuits, hence the appropriateness of the term "no-lawsuit." 
II

\section{Two "Neo-No-FaulT" Proposals}

Through the years, reform efforts have succeeded on several occasions in modifying tort law to provide more efficient and fairer payment for injury without regard to fault. The first great effort in this regard was workers' compensation, originally enacted in Germany in the late nineteenth century and in North America in the early twentieth century. Prior to workers' compensation, workers injured in the course of employment had to prove their employers' fault and their own lack of contributory fault. Enlightened employers in this country perceived the futile nature of the tort system as applied to employment injuries, entailing as it did both huge transaction costs and much uncompensated loss. Enacted with employers' support, workers' compensation sought to eliminate disputes over fault in industrial accidents and provide prompt payment of injured workers' economic losses. ${ }^{12}$

In recent years, no-fault auto insurance laws have sought to accomplish similar goals. ${ }^{13}$ In this instance, each motorist or other party injured in an auto accident is paid regardless of fault, but only for economic losses; with statutory exceptions, these benefits displace tort claims arising out of the accident. A recent U.S. Department of Transportation survey has indicated how strikingly effective no-fault insurance can be in providing quicker, surer payment at substantially lower cost than tort liability coverage. ${ }^{14}$

The success of these tort reform initiatives naturally prompts interest in using no-fault concepts to deal with iatrogenic injuries and the difficult problems of the law of medical malpractice. However, grave difficulties would obviously confront any system of no-fault insurance that undertook to compensate all those injured by medical treatment. The main problem would be how to define and recognize the insured event. Under no-fault auto insurance, it is seldom difficult to recognize an injury "arising out of the ownership, maintenance, or use of a motor vehicle." But can patients be similarly compensated for all conditions "arising in the course of medical treatment"? Would it not be difficult in many instances to know whether the patient's injury resulted from treatment or from the condition which sent him to the health care provider in the first place? Realistically, could a health care provider or his insurer be required to pay every patient whose condition worsens after treatment or who suffers some regrettable side effect?

Prompted by these difficulties and the seeming impasse in which the tort system is locked, this writer has recently made two proposals, one for legislation and one for private action, to ameliorate problems with the tort

12. Nat'l Comm'n on State Workmen's Compensation laws, Compendium on Workmen's Compensation 16-18 (M. Rosenblum ed. 1973). As to the greater efficacy of workers' compensation laws, with all their shortcomings, as compared to tort law, see Nat'l Comm'N ON STATE WORKMEN's COMPENSATION LAWS, REPORT 25, 45 (1972).

13. U.S. Dep't Transp., Compensating Auto Accident Victims: A Follow-up Report on NoFault Auto Insurance Experiences 1-24 (1985).

14. Id. at 3-6, 21-40. 
liability system as applicable to medical accidents. Because these plans do not contemplate total displacement of the fault system but hope to broaden the availability of automatic indemnification for net economic loss, they have been labeled "neo-no-fault" plans for present purposes. The following brief descriptions of these two proposals and their respective rationales are offered as a prelude to the subsequent discussion of how they complement one another and of their potential for amalgamation into a single neo-no-fault compensation scheme.

\section{A. A Scheme for Statutory Neo-No-Fault Compensation}

A version of the neo-no-fault legislation proposed by this writer ${ }^{15}$ has been introduced in Congress by Representatives Henson Moore and Richard Gephardt ${ }^{16}$ and is described in some detail in the article in this symposium by Congressman Moore and Washington attorney John Hoff. ${ }^{17}$ The basic concept is that a health care provider facing a potential or actual tort claim for personal injury would have the option to foreclose such claim by offering, within 180 days following injury, ${ }^{18}$ to pay the injured party's net economic loss, consisting in most cases of medical expenses and wage loss not covered by his own insurance, ${ }^{19}$ and reasonable legal fees. ${ }^{20}$ By statute, such a tender of net economic loss would totally satisfy any personal injury claim, except in cases of death or intentional injury. ${ }^{21}$ Payments would be made periodically as loss accrues, rather than in a lump sum. If the amount of compensable loss was disputed, arbitration would fix the amount due.

Under present law, either party is obviously free to offer to settle for the claimant's net economic loss. The difference is that, at present, neither party need accept such an offer, whereas the proposed statute would give the potential claimant no option to refuse. The obvious question is why the law should force such a settlement on a claimant. Is it fair? The answer to this question begins with a reminder that injured patients whose net economic losses are paid are being treated very well in comparison with most victims of misfortune in our society, whether from illness, injury, handicap, crime, 87.

15. O'Connell, supra note 5.

16. H.R. 3084, 99th Cong., 1st Sess. (1985); see Moore \& O'Connell, supra note 9, at 1267, 1278 -

17. See Moore \& Hoff, H.R. 3084: A More Rational Compensation System for Medical Malpractice, LAw \& Contemp. Probs., Spring 1986, at 117.

18. The original article proposed a limit of 60 days. O'Connell, supra note 5, at 601 . Whether the limit is 60,90 , or 180 days is largely a matter of the drafter's discretion. Sufficient time is needed, though, for a defendant to investigate the circumstances of the accident giving rise to the claim. Id. at 625 .

19. As a result of the political judgment of its congressional sponsors, H.R. 3084 calls for a tender of full wage loss, similar to reimbursement at common law. As an alternative, the level of wage loss could be defined objectively in an amount equivalent to the maximum weekly amount guaranteed for wage loss under the workers' compensation law of the victim's domiciliary state. Wage loss might also be indexed to inflation, but many insurers might resist it.

20. See infra text following note 35 .

21. For alternative means of delineating which tort claims are preserved, see Moore \& O'Connell, supra note 9 , at 1281-83. 
unemployment, or other mishap. Guaranteed prompt payment of all-or even the great bulk-of economic losses is a rarity for the seriously impaired. The theory behind the legislation, then, is that prompt payment to an injured patient of his economic loss is a fair disposition of his case, especially taking into account the prodigious expense, delay, and uncertainty of allowing pursuit of larger awards through tort litigation.

Another objection to the proposal's fairness might be that it benefits negligent health care providers by allowing them to foreclose actions for noneconomic damages. It can indeed be anticipated that providers will benefit by proffering tenders when their conduct has been clearly negligent and when a tort action therefore would be likely to result in a judgment much larger than the statutory benefit. It may also be feared that providers will elect not to make tenders in marginal cases involving only a small risk of liability and that the result of the legislation would therefore be simply a windfall to providers and little increase in the number of patients receiving compensation.

Despite these concerns, it is far from clear that providers or their insurers will be so disinclined to tender the statutory benefits. A decision to tender net economic loss will be made whenever the lump sum that the insurer must set aside to pay them is less than the sum of (1) the anticipated costs of a legal defense and (2) the likely recovery (appropriately discounted for the possibility that a claim will not succeed). The latter figure under the law of most jurisdictions must include, in addition to net economic loss, the amounts being paid to the victim from collateral sources and the amount likely to be awarded as noneconomic damages. For example, if injuries compensated by collateral sources and damages for pain and suffering would likely total $\$ 250,000$ and the defendant stands only a sixty percent chance of winning, the discounted value of such additional damages exceeding net economic loss would be $\$ 100,000$. Given the huge cost of litigating malpractice cases, the frequently substantial amounts covered by health and disability insurance, the potential for large awards for pain and suffering, and the uncertainty factor, the economic inducement to tender net economic loss will be substantial in many cases. In addition, defendants may favor tenders for noneconomic reasons, hoping to avoid the anguish, bitterness, and publicity of adversary litigation. A clue to the likely impact of the proposed statute on the incidence of litigation comes from a prominent defense attorney who, upon hearing the terms of H.R. 3084, told the author that he would be prompted to recommend settlement for net economic loss in forty-eight of fifty current cases in his office. ${ }^{22}$

The statute would also encourage providers to tender benefits by allowing them to extend immunity from suit to other parties who face a risk of being held jointly and severally liable for the injury in a tort action-a risk that is enhanced when the first provider obtains immunity by tendering net

22. Personal communication to author, Charlottesville, Virginia (April 1984). 
economic loss. ${ }^{23}$ Such a provision would give any provider contemplating a tender power to seek a contribution to the settlement fund from other parties involved in treating the patient-including such remote parties as a medical equipment manufacturer. If the tendering and third parties could not reach an immediate agreement concerning a third party's contribution, the third party's contribution would be established later through arbitration.

\section{B. Implementing the Neo-No-Fault Concept by Contract}

Because legislation of the kind proposed may not be enacted soon, ${ }^{24}$ the possibilities for achieving similar results by private initiative have also been considered. In the resulting proposal, ${ }^{25}$ it was suggested that a health care provider should purchase an insurance policy that would fund a tender of net economic loss to any patient injured in specified ways. ${ }^{26}$ The provider would also obligate himself or itself, prior to rendering services, to tender such payment to any patients suffering a covered injury within ninety days. Unlike the usual settlement offer, this tender would be made automatically and without regard to criteria of tort liability. Once the tender is made and by the express terms of the original undertaking, the victim and anyone with a claim based on the victim's injury (a family member, for example) would have an additional ninety days either to accept the offer or to claim in tort. ${ }^{27}$ If the claimant accepts the no-fault tender of net economic loss, he gives up the

23. The bill states that any physician or hospital or other health care provider that believes it is at risk of liability may make the tender to the injured patient. Such a provider may also designate any third person who may be liable as a participant in the tender. The issue of what amount, if any, the third person must contribute to the amount to be tendered would be determined in a separate proceeding. The third person so designated receives the same protection against tort claims as a tendering provider. Although a third person can thus be compelled to participate in the tendering process against his will, he will not be disadvantaged in that he thereby avoids exposure to liability for noneconomic tort damages (including pain and suffering), and can still dispute his liability under the tender.

Indeed, even without compulsion, third parties potentially liable in tort will feel enormous pressure to join in a tender. If third parties did not join, they would face a much more aggressive claimant, who, like a workers' compensation recipient pursuing a third-party tort claim, would have been assured of his or her basic losses and would thus be much more able to resist settlement offers than would a normal, impecunious injury victim. J. O'Connell, The LAwsuit LotTery 216 (1979).

24. For a description of the frustrations entailed in trying to pass legislation, see $\mathrm{O}^{\prime} \mathrm{Connell,}$ supra note 2, at 905-06.

25. Because the costs of such contracts will be difficult to predict, the neo-no-fault plan could be introduced in a pilot program which would limit coverage to a given area or period of time, or both. The findings from such a pilot program could be fully studied and evaluated before the neo-no-fault plan was implemented on a larger scale.

26. Here, too, as under the legislative proposal, net economic loss will encompass all medical expenses (including rehabilitation) and wage loss (up to, for example, three hundred dollars per week) which the injured party's own collateral sources, such as accident and health insurance or sick leave, do not cover. For a more detailed description of some aspects of the proposal, see O'Connell, supra note 2, at 906-10.

27. The policy could be drafted so that the party against whom a personal injury claim is made could, at its option, make the tender even before the claim is made. Thus, a potential payor could avoid waiting until just before the statute of limitations has run to tender the victim's net economic loss. Instead, it could do so at any time after injury, thereby starting the 90-day period within which the claimant would have to decide whether to accept the tender. As to whether the period should be 90 days or some other period, see supra note 18. 
right to sue for tort damages. This new proposal would not require a potential victim to waive his right to sue in tort prior to an accident. Instead, he must only choose, after an accident, whether to accept no-fault benefits or to pursue his tort action. Thus, any legal difficulties presented by a waiver of a legal right prior to the occurrence of an injury would be avoided. ${ }^{28}$ For legal purposes, the tender and its acceptance would operate simply as a settlement of the tort claim.

Obviously, in this instance, unlike the situation under the proposal to legislate neo-no-fault compensation, the health care provider and the insurer cannot force an unwilling injured person to accept payment of his net economic loss. Indeed, one might ask how offers under this plan differ from identical postaccident offers of settlement that can be made under present law. The key difference, and the one that makes this plan attractive, is the preaccident guarantee by the provider that it will make such an offer in the event an injury occurs. This guarantee removes adversary game-playing considerations from the potential defendant's decision to offer a settlement. Because the settlement offer is no longer discretionary, a defendant or an insurer need not fear that the offer to cover net economic loss will be perceived simply as an opening bid or as a signal of weakness, ${ }^{29}$ encouraging plaintiffs-and especially their lawyers-to hold out for more. Being made pursuant to a preaccident guarantee, the offer is not only certain to be made but is more likely to be accepted.

The objection usually made to the proposal that health care providers voluntarily commit themselves to make postaccident tenders of net economic loss upon the occurrence of a defined event is that such commitments will result in many more payouts without preventing patients from pursuing huge awards in cases where liability is relatively clear. Because injured patients retain the option to accept or reject payment of net economic loss, it can reasonably be feared that those with promising tort claims would opt to sue while only those with a poor prospect for a larger recovery would accept the tender. This scenario is unduly pessimistic, however. Those who have suffered serious injury could be expected to be quite risk-averse when it comes to choosing between, on the one hand, a certain, immediate benefit that, together with collateral sources, makes him economically-if not physically-whole and, on the other hand, an uncertain chance of eventually winning a much larger amount. Evidence to support the expectation that victims will accept offers of net economic losses comes from a program for

28. For a similar proposal, developed independently, see 1 President's Comm'n for the STUDY of Ethical Problems in Medicine and Biomedical and Behavioral. Research, Compensating for Research Injuries: A Report on the Ethical and legal Implications of Programs to Redress Injuries Caused by Biomedical and Behavioral. Research 148 (1982).

29. Concerning this point (that such a tender of net economic loss entails no signal of the defendant's tort liability), the preaccident definition of the insured event calling for tender would have to be sufficiently broad so as not to include only cases where there would be clear tort liability; otherwise, the tender would smack of a signal of the weakness of defendant's case. 
high school athletes adopted in 1982.30 Of twenty-one seriously injured athletes eligible for compensation under that program, twenty opted to accept the tendered benefits and to forego their right to sue in tort. The one athlete who declined compensation was a gymnast who recovered fully and had little economic loss but had a chance of recovering for pain and suffering.

Although the proposed contractual scheme for funding automatic tenders of net economic loss would save substantial litigation costs and reduce many damage awards, it could end up costing more than malpractice insurance if it undertakes to pay many claims that would not have been paid under a tort regime. Cost is not the only consideration, however, that would influence a provider's decision to adopt it. The prospect of avoiding the stigma and unpleasantness of malpractice suits and the opportunity to ensure reasonable compensation for patients injured whether or not as a result of provider fault might induce a provider to incur higher costs. Indeed, the wider and more dependable financial protection offered to patients under the proposed scheme might give the provider a competitive advantage that would more than offset any higher prices that might have to be charged.

There are several opportunities for lowering the cost to the provider of the contractual neo-no-fault scheme without diminishing its other attractions. One approach would be to provide in the contract that the victim, by accepting the tendered benefits, also loses his tort rights against any third parties whom the tendering party designates. This provision would permit bargaining with such third parties for a contribution toward the payment of net economic loss benefits. One possibility would be that third parties-for example, physicians practicing in a hospital undertaking to tender no-fault benefits-would share the premium burden, paying into the fund at the commencement of the policy period and becoming additional insureds under the policy. Alternatively, the provider initiating the scheme could reserve the right to designate the jointly and severally liable third parties who would be protected by the settlement at the time benefits were tendered, thus giving it

30. Telephone interview with Doug Rudlinger, insurance broker for the National Federation of State High School Associations (March 1986).

The author drafted the insurance contract discussed here to cover serious high school athletic injuries commencing with the 1983-84 academic year. The plan, drafted under the auspices of the National Federation of State High School Associations, is now in effect in 49 states, covering $60 \%$ of all U.S. high schools. This plan entails a neo-no-fault policy for unlimited medical expenses plus $\$ 300$ per week for wage loss payable to catastrophically injured athletes. The premium for such coverage is approximately $\$ 1.25$ per year for each athlete covered, and is paid by the school. (This cost may well be equalled-and perhaps exceeded-by savings in liability insurance costs from the tort waivers.) The plan has a $\$ 25,000$ deductible, meaning that the policy is triggered when medical and rehabilitation expenses and lost wages exceed that amount. No payment is made for pain and suffering.

As indicated above, the coverage goes into effect only if the beneficiary and his family agree not to file a tort suit against the school, school district, or state athletic association. As with the neo-no-fault plan suggested in the text, however, there is no preaccident waiver of legal rights here. After an accident, the injured party must decide whether to sign the contract and accept the benefits or to reject the contract and sue in tort. As stated in the text, so far all athletes who have been offered the plan have signed the contract and accepted the benefits. 
leverage to bargain for a contribution to the pool established to pay the specific victim.

Another way of reducing the cost of a preaccident commitment to tender compensation would be to limit the duty to pay for nonserious injuries. Victims of medical malpractice are less likely to pursue tort claims for minor injuries than are, say, victims of slips and falls or auto accidents. ${ }^{31}$ Knowing this, the health care provider has much less incentive to offer a no-fault compensation plan for such injuries. Accordingly, the provider might exclude smaller claims from the terms of the contract, stipulating that actual medical expenses or wage loss must exceed, for example, $\$ 25,000$ before a tender must be made. Further, the list of compensable events contained in the contract might be designed to include only medically serious injuries. For example, coverage might be limited to such adverse results of surgery as brain damage or loss of a limb or vital organ, with the stipulation that adverse results directly related to the normal progression of the original illness or disease are excluded from coverage ${ }^{32}$ Similarly, the same range of injuries could be covered when they resulted from a failure of diagnosis, although in this case there would be no limitation to effects whose origins were independent of the original illness or disease. ${ }^{33}$

Because injured parties to whom compensation for net economic loss is tendered do not lose their tort rights, they will often wish to retain a lawyer and to engage in discovery before deciding whether to accept the tender. The contract itself should probably affirm the health care provider's obligation to cooperate in such discovery. Although the ninety-day time limit for acceptance of a tender opens the door for footdragging in the disclosure of evidence of negligence, any plaintiff believing that a provider is stonewalling has two options. He could accept the settlement but later challenge it on the ground the provider behaved improperly; although a heavy presumption of validity attaches to settlements, ${ }^{34}$ proof of material nondisclosure of evidence of negligence would probably result in the settlement's being overturned. Alternatively, the injured patient could try for equitable relief to speed up the discovery process or to get an extension of the deadline for acceptance. ${ }^{35}$

31. This reluctance to pursue small claims is due to the fact that product and malpractice suits involve technical engineering and medical evidence, entailing the need for expensive expert witnesses. Consequently, only the most serious injuries justify such an investment. J. O'ConNELL, supra note 23, at 178; see First World Congress on Product Liability, Proceedings 177 (1977) (remarks of M. Belli); J. O'ConNELL, supra note 1, at 12-18, 41; O'Connell, An Elective No-Fault Liability Statute, 1975 INs. L.J. 261, 290-91.

Even when the provider's liability is relatively clear, a victim who suffers no residual injury has little incentive to sue for loss of a few thousand dollars. To pursue the case would often not be profitable for a competent plaintiff's attorney.

32. Certain instances of express assumption of risk might also be excepted, as with, for example, optional back operations where the risk of poor results are great.

33. This inclusion is because the failure of diagnosis leads to the normal progression of the (undiagnosed) disease or illness.

34. E.g., Thorn Wire Hedge Co. v. Washburn \& Moen Mfg. Co., 159 U.S. 423, 444 (1895).

35. The contract might well provide that if a recipient of benefits challenges the validity of the contract, the recipient must immediately return all amounts previously paid, the obligations to pay 


\section{Attorney Fees and Services}

Under both neo-no-fault proposals, the amount tendered to a patient to cover his net economic loss should include a reasonable fee for an attorney's services in connection with the determination and collection of the net economic loss. This compensation is necessary because no payment is made for pain and suffering. Under the present tort system the allowance for pain and suffering is often used, as a practical matter, to pay the plaintiff's attorney, thus preserving funds meant to replace wage loss or pay medical expenses.

Under the contractual proposal, the provision for attorney fees arguably should not cover, in addition to services related to payment of net economic loss, a lawyer's time and effort spent on investigating the wisdom of a tort action. Such time and effort should probably be deemed an investment by the lawyer that is recoupable only through contingent fees earned in normal tort actions. In any event, a claimant's lawyer who stands to receive a larger contingent fee in the event of tort litigation would have a conflict of interests in advising his client against accepting the tender of net economic loss. ${ }^{36}$ Thus, when a claimant rejects such a tender in favor of a tort action, the tendering party could offer to pay for a second opinion as to the wisdom of litigation from a lawyer who will certify that he will not, directly or indirectly, represent the claimant in a related tort action. Provision for such second opinions could be made in the contract.

\section{III}

\section{The Two Proposals Compared}

What are the similarities and differences between the foregoing legislative and contractual proposals, both of which contemplate that injurers should tender to injured parties their net economic loss? What are the comparable advantages and disadvantages of each approach? Are they mutually exclusive, or can they be coordinated?

The premise of both proposals is that, although guaranteeing no-fault benefits to all victims of medical accidents may pose seemingly insurmountable problems, those problems should not prevent the provision of such benefits to many victims. The two proposals necessarily proceed down different paths to this objective, circumventing the existing tort system by different routes.

The key difference between the two plans for neo-no-fault compensation lies in the discretion exercised by the respective parties. Under the contractual plan, the injurer is under a self-imposed contractual obligation to

\footnotetext{
further losses on a no-fault basis cease, and, if the defendant prevails in a subsequent trial, the recipient must pay the defendant's litigation costs.

36. Note that a plaintiff's lawyer who advises a seriously injured client to reject the prompt-but temporary-offer conferring essential losses might well be confronted with a legal malpractice action himself if the gamble of the medical malpractice action fails.
} 
tender no-fault benefits, while the injured party has a choice between accepting the tender and pursuing a tort action. In the case of the legislative plan, the injurer has a choice between tendering no-fault benefits and risking a tort suit, while the injured party is under a statutory obligation to accept the tender of benefits if it is made. In contrast to these two approaches, a complete no-fault system for all victims, such as statutory workers' compensation, operates by giving neither side an option: the injurer must tender, and the injured party must accept, the latter's economic loss. Under the common law, on the other hand, the injurer has the option of making or not making a postaccident tender of the injured party's economic loss (or any other amount), and the injured party has the option of accepting or not accepting any offer that is made.

If the common law approach is unsatisfactory and imposition of the pure no-fault alternative upon both parties is similarly unsatisfactory or impossible, two options remain: (1) requiring the injurer to tender specified benefits while leaving the injured party free to refuse the tender, or (2) requiring the injured party to accept a tender of specified benefits while leaving the injurer free not to make such a tender. ${ }^{37}$ Although either of these arrangements could theoretically be adopted by either contract or statute, there would be greater acceptance of private contracts achieving the former result-that is, one in which the injurer, rather than the weaker, more sympathetic injured party, has his options curtailed. This helps explain why a statute is thought necessary to cut off injured patients' malpractice rights upon receipt of a health care provider's discretionary tender of net economic loss. Rightly or wrongly, courts might be unreceptive to a provider/patient agreement that attempted to confer on the provider a similar power to force settlement of potential tort claims on advantageous terms. ${ }^{38}$

37. Another variation on this contractual device is legislative authorization of mutually binding preaccident contractual commitments to no-fault benefits in lieu of tort. O'Connell, Elective No-Fault Liability by Contract With or Without an Enabling Statute, 1975 U. ILt. L. Rev. 59; O'Connell, No-Fault Liability by Contract for Doctors, Manufacturers, Retailers and Others, 1975 INs. L.J. 531. This approach was widely followed in the case of elective workers' compensation. 2 A. LARson, WORKMEN's COMPENSATION LAW $\$ 67$ (1983). A further legislative variation would allow the injurer the option of a preaccident commitment to pay no-fault in lieu of tort, which would bind the injured party to nofault benefits. J. O'ConNELL, supra note 1, at 97-175, 204-45. In fact, almost anything would be better than the present system. See infra text accompanying note 43.

38. Lacking a statute, the injured party cannot be denied his right to refuse an offer of settlement. This explains the injured party's option under the contractual plan. But even by statute there is no workable way a defendant can be obligated to accept a claimant's tender of settlement. Such a scheme would allow a claimant to make almost random claims and extract payments for them. Thus, in order to encourage settlement for economic loss to a greater extent than under the common law, the proposed statute puts the injured party under an obligation to accept the injurer's tender of such benefits-which explains the injurer's option under the statutory plan.

It is important to keep in mind the crucial factor that, under both the legislative and contractual proposals, the tender of net economic loss is not a signal of weakness in the health care provider's case such that the plaintiff is thereby prompted to ask for more than net economic loss. Under the statutory plan, the plaintiff cannot turn down the tender; under the contractual plan, because the tender is made pursuant to a preaccident commitment (before the circumstances of the accident could have been known), plaintiffs cannot assume that the tender is a floor from which higher offers will spring. See supra pp. 118-19. 
The contractual approach to providing neo-no-fault compensation has the advantage over the legislative approach that it avoids the uncertainty, frustration, and pitfalls of adopting legislation. Unlike the statutory proposal, the contractual approach, once it is voluntarily implemented, commits the potential injurer to tender net economic loss for given injuries. Because the commitment is made on a preaccident basis, however, it presents the formidable problems, already noted with respect to proposals for comprehensive no-fault coverage of medical injuries, of defining the range of injuries for which no-fault benefits will be offered. ${ }^{39}$ The difficulty of specifying compensable events may limit the plan's utility.

Another shortcoming of the contractual approach is that it is feasible only for serious injuries and can do little about smaller, nuisance-type tort claims ${ }^{40}$ or claims involving small amounts of net economic loss. When the tendered payment is not large, an injured patient may find that it is not to his advantage to forego his right to claim in tort for pain and suffering and for economic loss covered by collateral sources. Thus, while the contractual device can ensure prompt payment of net economic loss when the injured party badly needs such help, it can do little to foreclose expensive, cumbersome, and unnecessary tort litigation when little economic loss has been suffered and the windfall potential seems bright.

This major failing of the contractual approach highlights a key advantage of the statutory tender plan. Discretionary tenders of net economic loss would be most likely when relatively little net loss had been suffered and a substantial tort recovery seemed probable. The difficulty with the statutory plan, however, is that, as previously suggested, the injurer may be unlikely to tender net economic loss when that loss is substantial and the tort claim looks defensible. Thus, the shortcomings of the statutory plan mirror the contractual plan's strengths, and vice versa. Neither plan can ensure both prompt payment of net economic loss to needy victims and the elimination of tort actions seeking primarily noneconomic damages, duplicative recoveries of wage loss and medical expenses, and extensive litigation expenses. Each system still leaves too much to the vagaries of tort litigation.

Despite their respective shortcomings, each proposal would eliminate some tort claims-which proposal would eliminate more claims is hard to say-and facilitate prompt coverage of many needy patients' net economic losses. The overriding point is simply that each plan offers substantial incentives to use dollars formerly misspent on investigating and litigating or settling tort actions to pay patients' real losses. Thus, both approaches should be simultaneously pursued: contracts should be implemented and legislation encouraged.

39. See supra text following note 14

40. O'Connell, A Proposal to Abolish Defendants' Payment for Pain and Suffering in Return for Payment of Claimants 'Attorneys' Fees, 1981 U. ILL. L. Rev. 333, 334-40. As noted earlier, however, smaller claims are not a major problem in the products liability and malpractice areas. See supra note 31 and accompanying text. 
IV

\section{The Two Proposals Combined: Legislation with Provision for Contractual Tenders of Net Economic Loss}

The suggestion that neo-no-fault compensation for medical injuries should be pursued simultaneously through both legislation and private contract may seem peculiar because passage of a well-drafted statute allowing health care providers to make binding tenders of net economic loss would remove the incentive for providers to make preaccident contractual commitments to make such postaccident offers. Why would a physician, hospital, or organized health plan make such a preaccident commitment to make offers that a claimant can turn down when the statute would allow discretionary postaccident tenders that a claimant cannot reject? The question suggests a need to modify the statutory proposal so that its enactment would not deter implementation of the contractual approach.

Because the statutory scheme fails to ensure compensation in many cases by leaving injurers with discretion not to tender, substantial benefits would flow from marrying the two schemes so that preaccident commitments would be encouraged. This blending could be accomplished by providing that any party who tenders net economic loss pursuant to a preaccident contractual commitment is entitled to indemnity from anyone tendering pursuant to a statute. Thus, a surgeon who had agreed in advance of surgery to pay for neurologic injury suffered as a consequence of surgery would be entitled to indemnification by a hospital that tendered after surgery out of fear of a tort suit against it for negligence in the administration of anesthesia. ${ }^{41}$

The dynamics of this proposal can be seen by pursuing several alternative scenarios:

(1) If the patient rejects the surgeon's obligatory contractual tender, the surgeon then has the option to make a (binding) statutory tender and will do so if he shares the injured party's opinion that a tort action is likely to benefit the latter.

(2) If the patient received either the surgeon's contractual or statutory tender, the patient's tort rights against the hospital (assuming it has no contractual obligation to tender) could be cut off by the latter's statutory tender, in which event the hospital must indemnify the surgeon's contractual obligation to cover net economic loss. In

41. To be more precise, the statute could thus provide, regarding the tenders of unlimited medical benefits plus a defined level of wage loss, that indemnification would be due any party tendering contractually from any party tendering statutorily. The level of wage loss could be defined objectively, in dollar amounts of, perhaps, $\$ 300$ per month or, in the alternative, in an amount equivalent to the maximum weekly amount guaranteed for wage loss under the workers' compensation law of the victim's domiciliary state. As a further alternative, the statute could leave the requisite terms of the contract entitling the contractual tenderer to indemnification for definition by a pertinent public official such as a state insurance commissioner or the Secretary of Health and Human Services, depending upon whether it is a state or federal law. Note that if the statute calls for greater wage loss to be tendered, allowing a lesser contractual tender would be an additional inducement to institute a contractual scheme because a contractual offeror will be liable for less wage loss. For example, if a party tendering pursuant to contract obligates itself to pay $\$ 300$ per week for wage loss, but the statute requires a tender of $\$ 500$ per week for wage loss, the party tendering pursuant to contract need never obligate itself to pay more than $\$ 300$ wage loss pursuant to a tender, and even payment of that lesser amount will be shifted to anyone tendering pursuant to statute. 
this way, the patient recovers his net economic loss and is unlikely to be left with a promising opportunity to sue either party in tort.

(3) The same would be true if the patient accepts the contractual offer and no offer is made by the hospital (either under the statute or in response to the surgeon's request to contribute to contractual benefits, because the hospital views its tort exposures as slight).

(4) If the patient declines the contractual offer and no statutory offer is made by the surgeon (who views his tort exposure as slight), the hospital may still make a statutory tender that may or may not include the surgeon.

As these scenarios show, combining contractual and statutory tenders can ensure both that fewer tort actions for noneconomic damages and pain and suffering are brought and that fewer economic losses suffered by injured patients go uncompensated. Although providers still retain discretion with respect to making preaccident commitments to cover particular injuries, the provision requiring statutory tenderers to indemnify the cost of contractual commitments will enhance the likelihood that such commitments will be made. Thus, amendment of H.R. 3084 to encourage the use of contracts implementing neo-no-fault compensation would seem desirable. Enactment of the modified federal proposal and of similar state statutes would go far toward ending the malpractice lottery on terms ensuring that patients' vital interests are well served.

\section{DETERRENCE}

An anticipated criticism of the proposals herein is that, in providing payment only for net economic loss, they undermine the value of tort damages in deterring injury-causing conduct. It is far from clear, however, whether adoption of either proposal would result in undesirable changes in the behavior of health care providers. In the first place, the assumption that negligence is effectively prevented by fear of legal liability and assessment of tort damages has been subject to cogent challenge. ${ }^{42}$ One set of questions concerns the effect of liability insurance, which diffuses financial responsibility. Moreover, in the medical context, pressure to achieve good treatment results comes from other sources, including professional pride, the fear of adverse publicity, concern for the opinion of associates and referring physicians, and the need to maintain hospital privileges and other relationships. It is also arguable that malpractice law's influence on provider behavior is not altogether beneficial, resulting in wasteful "defensive

42. For an effective indictment of the tort system, see Tullock, Negligence Again, 1 INT'L REv. L. \& ECon. 52 (1981); Tullock, Welfare and Law, 2 INT'L REV. L. \& Econ. 151 (1982). Tullock points out how very costly and wasteful the tort system often is in (1) its use of wasteful and manipulative adversary attempts at proving or disproving fault, (2) its likelihood of errors in determining fault, and (3) its failure to distribute losses. Tullock also emphasizes how legal-economic analysis often fails to consider the beneficial-and indeed economically efficient-results from no-fault or similar nontort schemes for payments.

For additional scholarly doubts about the deterrent effects of tort rules, see Epstein, The Social Consequences of Common Law Rules, 95 Harv. L. Rev. 1717 (1982); Pierce, Encouraging Safety: The Limits of Tort Law and Government Regulation, 33 VAND. L. REv. 1281 (1980). 
medicine" that fails to benefit patients either at all or enough to justify the high cost. Nor is it without significance that neither workers' compensation nor automobile no-fault laws are generally perceived as having weakened deterrence of careless conduct, ${ }^{43}$

It is similarly the case that the neo-no-fault plans offered here do not eliminate deterrent effects. The contractual scheme, by committing the provider to pay without regard to fault, creates incentives to avoid bad outcomes even when negligence is not their cause. Although both the legislative and the contractual proposals relieve providers from paying losses already covered by collateral sources, those proposals are hardly unique in this respect; statutes in several states currently allow deduction of collateral sources from malpractice verdicts as a way of preventing the waste of precious insurance dollars on duplication of amounts already compensated by other forms of insurance. ${ }^{44}$ Moreover, if great emphasis is given to the value of deterrence, it would be easy enough to modify either scheme to call for the tender to include reimbursement of collateral sources for their outlays. Thus, legislators or insurers interested in using the neo-no-fault device to avoid litigating over fault and the value of pain and suffering need not be dissuaded by the argument that deterrence must necessarily be sacrificed.

\section{VI}

\section{CoNCLUSION}

The tragic irony of the tort liability system is that it protects everyone connected with it except those who need protection most-the seriously injured whose losses outstrip their own collateral sources. Obviously, tort liability insurers are protected by distributing their risks with actuarial precision among their policyholders-and reinsuring to the extent they fear catastrophic losses beyond their own resources. Obviously, too, insureds are protected against personal financial loss; indeed, as a practical matter, tort claims are not brought except against insured defendants or corporate institutions that have opted for self-insurance. ${ }^{45}$ Defendants' lawyers are protected in that they are guaranteed payment for their services out of the insurance fund, win or lose. Even plaintiffs' lawyers are protected, despite

43. See U.S. Dep'T Transp., supra note 13, at 141-43, 159-66 (auto accidents); 2 F. HaRPER \& F. James, The LAW of TORTS $\$ 13.5$, at 775-76 (1956) (workers' compensation).

44. See, e.g., Cal. Civ. Code $\$ 333.1$ (a) (West 1985); P. Danzon, The Frequency and Severity of Medical Malpractice Claims 40-41 (The Rand Corp., Report No. R-2870-ICJ/HCFA, 1982). Given the huge amount of unreimbursed losses from injuries resulting from health care delivery, health care providers will continue to pay for large amounts of loss when they are paying for net economic loss, and losses will thus still be internalized to a significant degree compared to that being achieved at common law. Robinson, The Medical Malpractice Crisis of the 1970 's: A Retrospective, LAw \& Contemp. Probs., Spring 1986, at 14 n.50 (citing, among other sources, Cal. Medical Ass'N and Cal. Hosp. Ass'n, Report on the Medical Insurance Feasibility Study 103-05 (D. Mills ed. 1977)). The difference will be in the healthy result of using malpractice dollars to pay for individuals' losses not otherwise covered by insurance sources, rather than retransferring insurance dollars to insurance companies that are already covering losses. O'Connell, supra note 5, at 593.

45. James \& Law, Compensation for Auto Accident Victims: A Story of Too Little and Too Late, 26 ConN. B.J. 70, 78-79 (1951). 
their supposedly contingent fees, because they can turn down cases where recovery is unlikely and maintain a diversified portfolio of many cases that makes tolerable the loss of any single case. Injury victims whose economic losses are already compensated by collateral sources-in large measure, the less seriously injured-are also, by hypothesis, adequately protected. So, of all the parties to the series of transactions that lead to medical injuries and the subsequent allocation of the economic consequences of those losses, only those who need insurance the most-seriously injured patients whose losses significantly exceed their collateral sources-are left unprotected. Cruelly, they are left unable to learn when or what or whether they will be paid and are forced to pursue a long, agonizing, and uncertain path as their only alternative to financial as well as medical catastrophe.

By the devices described herein, tort liability insurance dollars could be better used, providing much greater protection for many seriously injured patients than does the lawyer-dominated common law tort system. 
